\title{
Microbial Contamination of Some Health Care Textile Products in Al-Ahsa Hospitals, Kingdom Saudi Arabia
}

\author{
Enaam M. Abou Zaid ${ }^{1}$, Nevine B. Ghanem ${ }^{2}$
}

\begin{abstract}
Textiles are common materials in health care requirements; therefore, hospitals laundering practices are critical to the prevention of transmission of pathogenic microorganisms, which could be the vector of many dangerous diseases. This study was conducted to study the microbial contamination of certain health care textile products in hospitals through both field and laboratory study. The field study revealed the presence of statistically significant relationship between microbial contamination of the hospital type, washing process, washer type, washing practice method, the amount of cleanser materials, as well as bleaching, disinfecting laundry, Ironing type, walls of the laundry, water source, sorting laundry, washing method used, the time of sterilization and storing the washed textiles.
\end{abstract}

The laboratory study which was conducted on some textile products used in hospitals during Laundering processes indicated that difference in the microbial content before and after washing of bed linen was $(59 \%)(74 \%)$; while the difference was $(33 \%)(24 \%)$ in doctors' clothes and for the patients' garments, it was $(56 \%)(30 \%)$.This may be due to the density of the threads and the weight per square meter $\left(\mathrm{yar} / \mathrm{m}^{2}\right)$. Microbial genera identified laundry on these textiles samples from different hospitals type revealed that gram negative was more persist laundry treatments and spread more than gram-positive bacteria. On the other hand, yeast species diminished completely after washing and this indicated that the washing agents used had a positive impact on the presence of yeasts.

Key wards: Health care textiles; hospital-acquired infections; textile hygiene; microorganisms.

\section{INTRODUCTION}

Microorganisms play an important role in human being life. In addition, they interfere in elements cycle in the environments; they inhabit soil, water, and the air close to soil surface. Natural fiber harbour a lot of microorganisms and their amount depends on different factors such as moisture and temperature, whether these fibers are from vegetable or animal origin. On the other hand, different types of synthetic fibers produced from polyamide or polyacrylic and polyester are inappropriate for the growth of microorganisms. Although microorganisms can grow in fiber fabricated from a mixture of cotton and polyester, Neely et al., (2004) showed that bacteria could survive for several days on different fabrics. This can be for more than one week depending on the bacterial type and the quality of fabric fibers, whether it was made from cotton or polyester.

Fabrics exposed to progressive wearing consumption due to soiling and washing processes and the accumulation of dirt, sweat and fat as a components of the skin making it a suitable environment for the growth of microorganisms (Rehab Abdel Hady, 2006). The textile products used in hospitals are the greatest tools in the field of medicine and surgery, because they include a broad range of continuous use products, which cannot be dispensed, as they are usually used for both patients and health workers to provide protection and safety (Heba Mabrouk, 2007; Parkash et al., 2002 and Ghosh, 2000). It is noteworthy that the textile products used in hospitals such as surgical gloves, headgear, face masks, towels, shoes covers, patients clothes must be characterized by the ability of absorption, high air permeability, and the lack of enforcement of fluids absorbed by the body. Also, it was found that there is a close relation between clothing material type whether it is made from natural or synthetic fibres, the form of model, the chemicals used, the tools and methods of care that has been used on the general health of humans (Manal Ahmed, 2010).

Recent studies confirm that the increased incidence of microbial diseases in hospitals is probably due to microbial contamination of textiles including the inappropriate washing operations, and the material types of the textiles used in hospitals. Some textiles are made from a mixture of cotton and polyester, and cannot tolerates the necessary high temperatures required for cleansing and cleaning at low temperature and thus helps the survival of pathogenic microorganisms. Microorganisms may harbour the textiles in hospital such as patients and medical staff clothing, napkins, curtains, furniture, barriers and the floors coverings, and they have a significant effect on the performance of hospitals and staff working in the medical services (Khadija Gashgar, 2005). Hospitals give great importance and effort to the issue of the provision of clothing, bedding and their cleanness as they have a significant effect on its performance including working staff and the nature of the medical services provided to patients, as well as it accounts for a

Faculty of Education, King Faisal University

Kingdom Saudi Arabia.

${ }^{2}$ Faulty of Agriculture and Food Nutrition.

Received June 7, 2016, Accepted June 27, 2016 
high percentage of the expenses allocated for these hospitals (Fijan et al., 2007). In the recent years, accusations were directed to furnishings of beds, mattresses, sheets, pillows, blankets and hoods. Khadija Elaali, (2008) has indicated in her study of microbial contamination in armed forces uniform and its impact on public health in hospitals of the armed forces in AlTaif hospitals, that the hospitals form a special environment for microbial contamination, which is one of the most serious problems faced by workers in healthcare and patients.

The efficiency of the cleaning process, whether manual or automatic moist or dry processes has great effect on the life cycle of textile. It maintains the health and safety of the individual if used in the optimal way, the effect of detergent and other additives used during washing process may adversely or positively affect both the mechanical and physical properties of the fabric and the consumer protection from certain illnesses. Breen et al., (1984). On the other hand, the cleaning process includes a range of factors affecting the efficiency of the process. These factors include both the type and concentration of detergent, the washing water temperature, mechanical washing, additives of disinfectants, softeners, bleaches, the number of times, and the method of rinsing, as well as drying. Also, other affecting factors are knowledge of the contaminant and the properties of the fabric in terms of the nature of the surface of the fabric, including its capillary characteristic. All these characteristics and factors also affecting the efficiency of the cleaning process (Hanan Al Gamel, 1998).

Medical textiles play an important role in infection control, personal protection and support healing processes. The use of medical textile products functions as a highly effective anti -microbial, which takes effect quickly, for example, in a matter of minutes, which can reduce the rate of infection in the hospital, and have a positive effect on the psychological and social state regarding relations between staff and patients.

Sonia Shipoon, (2009) reported that in order to prevent diseases transmission through fabrics especially with fungi, the fabrics have to be ironed to kill and remove fungi, and also can be boiled (clothes) and left for three days in the sun before use. Huda Ismail, (2007) mentioned that hospitals can get prepared textiles against microbes and fixed for repeated washing. It has been found that the white coats got contaminated after cleaning the wounds of patients and that the bacteria which contaminated coats consisted of a number of pathogenic bacteria and non- pathogenic bacteria, and some skin bacteria such Staphylococcus and Bacillus species. Many studies explained contamination of nursing staff clothes with live microorganisms. (Loh et al., 2000). Therefore, the clothes used in hospitals may be a means of transport of bacteria and pathogenic fungi (Callaghan, 1998). The washing processes with various stages may reduce the causes of various diseases, but the Bacillus bacteria, which are heat resistance type, may remain (Barrie et al., 1994).

In a recent study, Teufel et al., (2008) used molecular genetics technique to isolate DNA as a quick and accurate way to estimate the number of organisms in textiles before and after cleaning in order to maintain the health and safety of patients and auxiliary bodies that use textile products in hospitals. The use of high quality standards contributes to the protection and safety of staff in the healthcare industry. Over the centuries, history has shown that health interventions and investments were always a good plan to improve the country's economy.

Some hospitals washes textile products in a manner and means that may generally seem correct but they are actually wrong, based on preventive health standard and this leads to the transmission of certain diseases to consumers from doctors and patients. Because patient safety is the cornerstone of health care and the quality of medical supplies and the importance of the hospital as a place for healing, it should be at the highest level of security, safety and health. The hospital managers should improve the performance, the quality and safety of services provided to patients and staff. According to various reports from World Health Organization (WHO), hospitals are the largest microbial contamination sources.

The main goal of this study was to examine the effects of laundry and cleaning practices commonly used in hospitals for washing storing and disinfecting health care textiles on the microbial loads in these health care textiles before and after treatment.

\section{MATERIALS AND METHODS}

\section{Research method}

This study used the descriptive method of field study on the health care operations of textile products in some hospitals in the province of al-Ahsa and experimental approach to conduct laboratory experiments related to textile products and microbial contamination.

\section{The field study}

\section{Research area and sampling}

The study was conducted on ten intended selected hospitals some of them were public and other were private hospitals (Maternity, Otolaryngology, Paediatrics and multi-disciplinary hospitals) in the 
governorate of Al-Ahsa province Kingdom Saudi Arabia to participate in the study to fill out the questionnaire and microbial survey was applied in the study during the period from February till April 2013.

\section{Study Tools}

The questionnaire used by personal interview to meet the research data of those in charge of the affairs of the health care textile products of hospitals. The parameters of the questionnaire included several key items: general data about the hospital, individuals responsible for the washing process, the laundry, place of gathering, sorting clothes and dirty as well as clean linen, washing, sterilization, dryers, and ironing as well as the laundry cleanliness and safety.

\section{Laboratory study}

\section{Measurement of the physical properties}

The measurement of the physical properties of the textile were studied to measure (weight per square meter, and the density of the threads) of some textile samples products in hospitals such as bed sheets, staff uniform (doctors), patients wear and in accordance with US standards (ASTM-D3776-98) (2008), ASTM3775-98 (2008) and the laboratory support textiles Fund.

\section{Microbiological sampling}

About 150 samples were obtained from five different public or private hospitals (Maternity, Otolaryngology, Pediatrics and multi-disciplinary), 15 samples swabs (two sampling points) were collected using sterile cotton swabs from the outside surface of the samples (bed sheets, doctors uniforms and patients wear) before and after washing at each hospital.

\section{Microbiological analysis}

The collected swabs samples were transported and inoculated in a nutrient broth medium to the laboratory and were cultured onto in different media of blood agar medium, MacConkey and Mannitol agar for the isolation of bacterial cultures. Sabaroud dextrose agar medium supplemented with Ampicillin (50 mg/ 1) to inhibit the growth of bacteria (Oxoid, England) was used for the isolation of yeast and various fungi. The plates were monitored for microorganisms' growth, after $24 \mathrm{~h}$. At $37^{\circ} \mathrm{C}$ for the bacterial culture and for 48 $\mathrm{h}$ for fungi and yeast cultures. Morphologically different bacterial isolates from each plates were selected. The purification of the isolated colonies depending on the external appearance, colour and texture and the edge of the colony was done using streak- plate method to isolate Gram-positive (Staphylococcus aureus) bacteria, Gram-negative bacteria (E. coli), and yeast (Candida albicans). The isolated bacteria transferred to Plate Count Agar (AES
Chemueux) to identify the isolates bacteria to species level using the API 20E bacterial identification test kits (BioMereux, Marcy L'Etoile, France) strips for gram negative E. coli bacteria. On the other hand Gram positive cocci and catalase -positive, tube coagulase positive ,slide coagulase positive (Arthi et al., 2003) and polymixin B-resistant colonies were cultured on CHROMagar MRSA (BD Diagnostics Sparks, MD) to confirm identification as MRSA. Purified bacterial cultures were maintained on nutrient agar slants for storage at $4^{\circ} \mathrm{C}$ with regular transfer at monthly intervals. Fungi and yeast isolates have been inoculated into Sabaroud dextrose agar and identified by using Scotchtest examination.

\section{Gram's stain}

Isolated bacterial cultures were examined microscopically using Gram's stain to differentiate gram positive and negative bacteria, and it has been confirmed by using potassium hydroxide carefully by mixing $3 \% \mathrm{KOH}(\mathrm{w} / \mathrm{v})$ with portion of pure colony on glass slide and when not configured to be mucus confirms positive bacteria per gram (Arthi et al., 2003).

\section{Statistical and data analysis}

Statistical tests were done using Chi Square analysis, simple and multiple regression analysis, and Anova (Analysis of Variance).

\section{RESULTS AND DISCUSSIONS}

\section{Field study}

According to the chi square analysis of the field questionnaire results Table (1) indicates that there is a significant statistically relation at level $(0.01)$ between the microbial contamination in hospitals and hospital types, the washing process workers, the medical examination of workers, laundry type, the washing practice method, the amount of cleaning materials, as well as bleach, laundry sterilization and the ironing method. The study also proved that there is a significant statistically relation at level $(0.05)$ between the microbial contamination and all wall types of the laundry, water sources, sorting laundry, washing method used, sterilization and safe washing. The research results indicated no significant relationship between the microbial contamination of hospitals and the academic qualifications, experience level, the period for the medical examination, an inspection of the laundry, floor type, sorting, clean clothes storage, washing types that are sterilized, and drying laundry.

According to the international institute, there is a set of standards for the evaluation and determination of the laundry level including the existing washing process in terms of academic qualifications, years of experience, medical examination of laundry workers. 
Table 1. Relation between the type of hospitals and the quality of laundry microbial contamination

\begin{tabular}{|c|c|c|c|c|c|}
\hline Data & $\begin{array}{c}\text { Chi Square } \\
\text { Value }\end{array}$ & $\begin{array}{c}\text { Statistical } \\
\text { significance }\end{array}$ & Data & $\begin{array}{c}\text { Chi Square } \\
\text { Value }\end{array}$ & $\begin{array}{l}\text { Statistical } \\
\text { significance }\end{array}$ \\
\hline Hospital Type & 6.4 & $* *$ & The basis of the sort laundry & 3.80 & - \\
\hline Based washing process & 6.4 & $* *$ & Washing method used & 6.20 & $*$ \\
\hline $\begin{array}{l}\text { Academic } \\
\text { Qualifications }\end{array}$ & 0.80 & - & Style washing practice & 6.40 & $* *$ \\
\hline Years of Experience & 3.20 & - & $\begin{array}{l}\text { The amount of cleaning } \\
\text { materials }\end{array}$ & 9.80 & $* *$ \\
\hline $\begin{array}{l}\text { Medical examination } \\
\text { of workers }\end{array}$ & 6.40 & $* *$ & Addition of bleaching materials & 6.40 & $* *$ \\
\hline $\begin{array}{l}\text { The time period for the } \\
\text { medical examination }\end{array}$ & 1.60 & - & Clean laundry Storage & 3.20 & - \\
\hline Laundry inspections & 3.60 & - & Washing sterilization & 9.80 & $* *$ \\
\hline Laundry type & 6.40 & $* *$ & Sterilization time & 3.60 & $*$ \\
\hline The laundry floor type & 2.00 & - & Washing types that are sterilized & 1.60 & - \\
\hline The laundry walls type & 3.60 & $*$ & Washing dryers & 1.60 & _- \\
\hline Water Sources & 3.60 & $*$ & Method of ironing & 6.40 & $* *$ \\
\hline Washing sorting & 3.60 & * & Clothes storage after ironing & 6.20 & $*$ \\
\hline
\end{tabular}

* Statistically significant at 0.05 level; ** statistically significant at the 0.01 level; - Not significant

Sink kind including (ground type, type of walls, water sources); washing process comprise sort of laundry, washing method, amount of detergents and bleach used, washing sterilization, dryers, pressing and laundry storage) and that these standards affect the efficiency of the work in hospitals and maintain its healthy level. (Hanan Al Gamel ,1998).

\section{Laboratory study}

A-Effect of physical properties of heath care textile products used at hospitals (bed sheets, staff uniform (doctors), patients wear) on the microbial content before and after laundry

The impact of physical properties on the microbial contents of textile products is shown in Table (2). For bed sheets, the microbial content increased before washing at a rate of 0.94 unit for each one-unit increase in the density of threads, while the microbial content was increased at a rate of 1.2 unit after washing. The value of $\mathrm{R}^{2}$ (coefficient of determination) indicates that $42 \%, 23 \%$ of the changes in the microbial content before and after washing may be related to the threads density. Other changes may be due to other factors that were not included in the estimated function. In addition, the calculated value of $F$, which reached about (16.4), and (6.8) indicates the significance of the model, which was estimated at a confidence level of $95 \%$. As for the effect of weight per square meter, it was found that the microbial content increased at a rate of 3 units for each increase in the weight of one gram per square meter before washing while microbial content was increased at a rate of 39 units after washing. The value of R2 indicates $73 \%, 58 \%$ from changes in the microbial content before and after washing due to the weight in grams per square meter. The calculated value of $\mathrm{F}$, which reached about (62.9) and (32.1) indicates the meaning of the model which is estimated at a confidence level of $95 \%$. As for the effect of the density of threads and the weight per square meter on the microbial content, it was clear from the results that $74 \%$ and $59 \%$ from changes in the microbial content before washing and after due to both factors. The calculated value of $F$, which reached to (30.7) and (15.8) indicates the significance of the model which is estimated at a confidence level of $95 \%$.

Ghada El said, (2014) indicated that the natural properties of the fabric, which comprise both count weft and wrap and square meter weight in addition to the type of fabric, had an impact on the types of resistance of microorganisms (fungi). When an appropriate environmental condition is available, the textile materials usually exposed to many influences that may affect them and lead to their damage and erosion, which facilitate their ability of transmission of certain diseases. 
Table 2. Effects of the physical properties of textile products used at hospitals on the microbial contents

\begin{tabular}{|c|c|c|c|c|c|}
\hline $\begin{array}{l}\text { Type of } \\
\text { textile } \\
\text { product }\end{array}$ & $\begin{array}{l}\text { Physical } \\
\text { characteristics }\end{array}$ & $\begin{array}{l}\text { Washing } \\
\text { Process }\end{array}$ & *Equation & $\begin{array}{l}\mathbf{R}^{2} \\
(\%)\end{array}$ & $\mathbf{F}$ \\
\hline \multirow{6}{*}{ Bed Sheets } & Threads density & \multirow{3}{*}{ Before Washing } & $Y 1=-40.3+0.94 \times 1(4.04)$ & 0.42 & 16.4 \\
\hline & $\mathrm{wt} / \mathrm{m}^{2}$ & & $Y 1=-45.6+0-3 \times 1(7-9)$ & 73 & 62.9 \\
\hline & $\begin{array}{l}\text { Threads density } \\
+\mathrm{wt} / \mathrm{m}^{2}\end{array}$ & & $\begin{array}{r}\mathrm{Y} 1=-48.1+0.12 \mathrm{X} 1+0.25 \mathrm{X} 2 \\
(0.53)\end{array}$ & 74 & 30.7 \\
\hline & Threads density & \multirow{3}{*}{ After Washing } & $\mathrm{Y} 2=-31.5+1.2 \mathrm{X} 1(2.6)$ & 23 & 6.8 \\
\hline & $\mathrm{wt} / \mathrm{m}^{2}$ & & $Y 2=-51.3+0.39 \times 2(5.7)$ & 58 & 32.1 \\
\hline & $\begin{array}{l}\text { Threads density } \\
+\mathrm{wt} / \mathrm{m}^{2}\end{array}$ & & $\begin{array}{r}Y 2=-45.3-0.3 X 1+0.4 X 2 \\
(-0.6)\end{array}$ & 59 & 15.8 \\
\hline \multirow{6}{*}{$\begin{array}{l}\text { Doctors } \\
\text { clothes }\end{array}$} & Threads density & \multirow{3}{*}{ Before Washing } & $\mathrm{Y} 1=-1.5+0.23 \mathrm{X} 1(3.0)$ & 28 & 8.8 \\
\hline & wt $/ \mathrm{m} 2$ & & $\mathrm{Y} 1=-41.7+0.3 \mathrm{X} 2(2.9)$ & 27 & 8.4 \\
\hline & $\begin{array}{l}\text { Threads density } \\
+\mathrm{wt} / \mathrm{m} 2\end{array}$ & & $\begin{array}{rr}Y 2=-27.1+ & 0.15 X 1+0.17 X 2 \\
(1.38) \quad(1.28)\end{array}$ & 33 & 5.3 \\
\hline & Threads density & \multirow{3}{*}{ After Washing } & $\mathrm{Y} 2=-3.5+0.1 \mathrm{X} 1(2.7)$ & 24 & 7.3 \\
\hline & wt $/ \mathrm{m} 2$ & & $\mathrm{Y} 2=-41.7+0.29 \mathrm{X} 2(2.9)$ & 27 & 8.4 \\
\hline & $\begin{array}{l}\text { Threads density } \\
+\mathrm{wt} / \mathrm{m} 2\end{array}$ & & $\begin{array}{c}\mathrm{Y} 2=-1.9+0.10 \mathrm{X} 1-0.01 \mathrm{X} 2 \\
(2.08) \quad(-0.17)\end{array}$ & 24 & 3.5 \\
\hline \multirow{6}{*}{ Patients wear } & Threads density & \multirow{3}{*}{ Before Washing } & $\begin{array}{c}\mathrm{Y} 1=150-2.04 \mathrm{X} 1 \\
(-2.1)\end{array}$ & 16 & 4.5 \\
\hline & $\mathrm{wt} / \mathrm{m} 2$ & & $\begin{array}{r}\mathrm{Y} 1=113.2-0.54 \mathrm{X} 1 \\
(-5.3) \\
\end{array}$ & 55 & 28.6 \\
\hline & $\begin{array}{l}\text { Threads density } \\
+\mathrm{wt} / \mathrm{m} 2\end{array}$ & & $\begin{array}{r}\mathrm{Y} 1=85.8+0.6 \mathrm{X} 1-0.6 \mathrm{X} 2 \\
(0.66) \quad(-4.5)\end{array}$ & 56 & 14.2 \\
\hline & Threads density & \multirow{3}{*}{ After Washing } & $\begin{array}{c}\mathrm{Y} 2=68.5-0.96 \mathrm{X} 1 \\
(-1.7)\end{array}$ & 11 & 2.9 \\
\hline & wt $/ \mathrm{m} 2$ & & $\begin{array}{r}\mathrm{Y} 2=46.6-0.22 \mathrm{X} 2 \\
(-3.1)\end{array}$ & 30 & 9.7 \\
\hline & $\begin{array}{l}\text { Threads density } \\
+\mathrm{wt} / \mathrm{m}^{2}\end{array}$ & & $\begin{array}{rr}Y 1=43.8+0.1 \mathrm{X} 1- & 0.23 \mathrm{X} 2 \\
(0.1) & (-2.4) \\
\end{array}$ & 30 & 4.6 \\
\hline
\end{tabular}

Y1: microbial contents before washing

$\mathrm{X} 1$ : warp density, $\mathrm{X} 2$

Y2: microbial contents after washing

$\mathrm{t}$ : Values in brackets is the value of the calculated $(\mathrm{t})$

For the doctors clothes the microbial content increased before washing at a rate of 0.23 units for each increase in the density of threads, while the microbial content was increased at a rate of one unit after washing. As indicated by the value of $\mathrm{R}^{2}$ (coefficient of determination), $28 \%$ and $24 \%$ of the changes in the microbial content before and after washing that may be due to the density of the threads. The rest of the changes are due to other factors that are not included in the function. The calculated of $(F)$ value, which reached (8.8) and (7.3), indicates the significance of the model, which is estimated at a confidence level of $95 \%$. As for the effect of weight per square meter $\left(\mathrm{wt} / \mathrm{m}^{2}\right)$, it was found that the microbial content increased at a rate of 3.0 units for each increase in the weight of one gram per square meter before washing while microorganisms were increased at a rate of 29 units after washing. The value of $\mathrm{R}^{2}$ indicates that changes in the microbial content before and after washing are equal (27\%) due to the weight in grams per square meter. Where the calculated value of F, which reached (8.4), indicates the significance of the model that is estimated at a confidence level of $95 \%$. As for the effect of the density of threads and the weight per square meter on the microbial content, it was clear from the results of $33 \%$ and $24 \%$ of changes in the microbial content before washing and after due to both factors. The calculated value of F, which reached to (5.3) and (3.5), indicates the significance of the model which is estimated at a confidence level of $95 \%$. 
For the patients clothes the microbial content increased before washing at a rate of 2.04 units for each increase in the density of threads by one unit while the microbial content was increased at a rate of 96 units after washing. As indicated by the value of $\mathrm{R}^{2}$ (coefficient of determination), $16 \%$ and $11 \%$ of the changes in the microbial content before and after washing may be due to the density of the threads. The rest of the changes due to other factors that are not included in the function. The calculated value of $\mathrm{F}$, which reached (5.4) and (2.9), indicates the significance of the model, which is estimated at a confidence level of $95 \%$. As for the effect of weight per square meter it was found that the microbial content was increased at a rate of 54 units each increase in the weight of a meter one gram before washing while microbial content is increasing at a rate of 22 units after washing. As indicated by the value of $\mathrm{R}^{2}$ (coefficient of determination), $55 \%$ and $30 \%$ on changes in the microbial content were due to the weight in grams per square meter. The value of $\mathrm{F}$ calculated, which reached (28.6) and (9.7) indicates the significance of the model, which is estimated at a confidence level of $95 \%$. As for the effect of the density of threads and the weight per square meter on the microbial content, it was clear from the results that $56 \%$ and $30 \%$ of the changes in the microbial content before washing and after due to both factors. The calculated value of $F$, which reached (14.2) and (4.6), indicates significance of the model which estimated statistically.

B. Determination of microorganisms in textile products used in hospitals

Microbial contamination of health care textiles used in hospitals include bed sheets, doctors clothing and patients clothing may be a vehicle for the transfer of certain pathogens to doctors and patients and their widespread in hospitals. This study was conducted to indicate the possibility of the presence of microbial contamination in different hospital textiles before and after laundry and processing in a number of public hospitals with different activities. Results indicated a wide range of microorganisms could be isolated from health care textiles including gram positive, gramnegative bacteria and a few species of yeasts. The analysis of variance (Anova) indicated a significant results and a positive effect of different laundry treatments in hospitals. A significant difference was observed in the gram-positive bacteria isolated from different textiles at the level, (p 0.005) (Table 3). Also results showed a highly significant difference at $(\mathrm{P}$ 0.005 ) for the number of positive bacteria found in patients clothes before and after different laundry treatments with values $(202.500$ and 30.267) respectively.

Other studies showed that some microbes could remain viable for one day on all kinds of textiles as Staphylococcus bacteria and they were able to grow and been active on textiles made from polyester for a period range from 1 to 56 Days (Neely and Maly, 2000). Also this was in agreement with results of Pinon et al., (2013) as it was clarified that bed sheets may be a reservoir of microorganisms and could be a vector of disease transmission. In addition pollution might occur after the wash process and that most of the bacteria isolated from the samples belonged to the natural flora on the skin (Hooker et al., 2012) and bacteria responsible for many of the bed sheets infections. This is consistent with results reported by Pittet and Wenzel (1995). Also, the excessive use of antibiotics may affects mutations in this types of grampositive bacteria, which increases the chances of infection in the hospitals (Klevens et al., 2007; Boyce et al., 2004; National Nosocomial Surveillance System, 2002; Herold et al., 1998).

Contamination with Streptococcus bacterial isolates were also found (Rao et al., 1988). Barrie et al. (1994) found that contamination with Bacillus cereus were remained on the bed linens after washing where the bacteria resists heat and chemicals used in the process of laundry. The study showed the proliferation of these bacteria increase when sheets are stored in plastic bags, which provide the appropriate humidity and temperature adequate for bacterial growth.

Table 3. analysis of variance and comparison between the average numbers of the gram positive, gram negative and disincentives yeast in samples from the hospitals under study

\begin{tabular}{|c|c|c|c|c|c|c|c|}
\hline \multirow{2}{*}{$\begin{array}{l}\text { Type of } \\
\text { textile } \\
\text { product }\end{array}$} & \multirow[t]{2}{*}{$\begin{array}{l}\text { Washing } \\
\text { Process }\end{array}$} & \multicolumn{2}{|c|}{$\begin{array}{c}\text { Gram positive } \\
\text { Bacteria }\end{array}$} & \multicolumn{2}{|c|}{ Gram negative Bacteria } & \multicolumn{2}{|c|}{ Yeast } \\
\hline & & $\begin{array}{c}\text { Mean } \\
\text { Square }\end{array}$ & Sig. & $\begin{array}{c}\text { Mean } \\
\text { Square }\end{array}$ & Sig. & $\begin{array}{c}\text { Mean } \\
\text { Square }\end{array}$ & Sig. \\
\hline \multirow{2}{*}{$\begin{array}{l}\text { Bed } \\
\text { Sheets }\end{array}$} & Before & 152.400 & $.00^{\circ}$ & 201.600 & 0.012 & .000 & 0.001 \\
\hline & After & 62.400 & .003 & 50.400 & 0.001 & 0.000 & 0.000 \\
\hline \multirow{2}{*}{$\begin{array}{l}\text { Doctors } \\
\text { clothes }\end{array}$} & Before & 38.400 & .052 & 165.600 & 0.001 & 3.600 & 0.003 \\
\hline & After & 9.600 & .010 & 21.600 & 0.000 & 0.000 & 0.000 \\
\hline \multirow{2}{*}{$\begin{array}{l}\text { Patients } \\
\text { wear }\end{array}$} & Before & 202.5 & $0.000 * *$ & 2175.600 & 0.000 & 6.000 & 0.006 \\
\hline & After & 30.276 & $0.001 * *$ & 88.267 & 0.016 & 0.000 & 0.000 \\
\hline
\end{tabular}


Results summarized in Table (3) of samples obtained from bed sheets and doctors clothes showed significant differences before and after processing with values $(152.400,62.400,38.400,9.600)$, respectively and the gram negative bacteria were the most prevalent with high statistical significance at $(\mathrm{P} \quad 0.05)$. The results showed a highly significant in the existence of gram-negative bacteria and they were the most widely found genera over the gram-positive bacteria in all samples examined in the various hospitals Table (3). The analysis variance revealed that gram negative bacteria are more spreading in samples of sheets before washing with significance of 0.012 , as well as doctors and patients clothes with values of $(0.001,0.00)$ respectively (Table 3). Laundry operations and different processing of samples showed, significant impact on the number of negative bacteria on the samples with high significance results $(0.001,0.00,0.016)$ which shows the importance of successful laundering processes which are dependent on several factors including the oversee of laundry before and after washing and the optimized conditions of all factors such as the types of washing machines used, work surfaces, storage places, workers in these places (Fijan et al., 2007). This is important to achieve a hygienic laundering procedure for hospitals health care textiles and not leading to microbial transfer after washing process. This results are in agreement with other researchers (Ensayef et al., 2009; Moataz, 2005; Bilal et al., 2002; Franklin et.al., 1997; Pittet and Wenzel, 1995; Hirai, 1991).

The survival rate of yeast species on textiles after laundering procedure was not detected and the processing of laundry, addition of disinfectants and ironing facilities had a positive impact on the number of pathogenic yeasts as Candida albicans in all samples. The gram positive bacteria remain for a long period up to several weeks in dry conditions ( Lidwell and Low Bury, 1950) therefore recommend to get rid of those microbes using the conduct of good cleaning, sterilization processes for textiles in different hospitals (O'Connor, 2000). From this study it was found that the detected gram negative bacteria belonged to the genus E.coli was agreed with Ensayef, (2009) in which it was proved that the fluids from patients are the main source of microorganisms transfer and the main causative agents of contamination (Cardo et al.,1993; Emori et al., 1990). Also the genus Pseudomonas aeruginosa was harbored in health care textiles after washing and this is due to that some of the microorganisms may persist in the used disinfectants and they prefer to grow in humid environment and persist in textiles, also some species mutated due to its resistance to several antibiotics and disinfectants which make it the source of infection in hospitals in case there is no good protocol to follow in laundry procedures (Pena et al., 2003; Bellido and Hancock, 1994).

The study found that the isolated negative bacteria was E.coli these findings are coherent with other author (Ensayef, et al., 2009) and that it became clear that the laundry of various textiles may be insufficient to get rid of all the organisms or germs. It became clear to the study that the bacteria may harbor within the threads of the textiles and that the existence of a protocol and follow-up must be taken into account in the future (El Schahawi et al., 2010) and that the use of processed textiles may be the treatment.

\section{RECOMMENDATIONS}

According to the field study results it was recommended that laundry departments in hospitals should be provided with proper modern washing equipments, air-drying and ironing facilities. The use of disinfectants with detergents, where their presence would lead to the elimination of microbes for use cleaners only. Follow the correct ways counting laundry and according to the color of the material and the degree of dirt and intended use with laundry collection more than once and provide the proper way to combine to prevent further contamination of dirty laundry. The sterilization of patients clothes and make sure they are free from microbes. Storage of textile products in clean places well ventilated according to health parameters. The continuous training and workshops for good clinical practices for washing process in order to increase the efficiency of the work. Attention to the need to use textile products equipped with resistance to living organisms in hospitals.

\section{ACKNOWLEDGEMENTS}

The research financed by the Deanship of Scientific Research, King Faisal University. Kingdom Saudi Arabia (Project number 140094). 2013-2014.

\section{REFERENCES}

Annual Book of ASTM standard. 2008.ASTM D3775-98 standard test method for warp (end) and filling (pick) count of woven fabric

Annual Book of ASTM standard. 2008. ASTM D3776-98 standard Test Methods for Mass per unit Area (weight) of fabric.

Arthi K., B. Appalaraju and S. Parvathi.2003. Vancomycin sensitivity and $\mathrm{KOH}$ string test as an alternative to Gram staining of bacteria. Int. J. Med. Microbiol.; 21: 121-123.

Barrie D., J. Wilson ،J. Kramer and P. Hoffman. .1994. "Contamination of hospital linen by Bacillus cereus ". Epidemiol infect. 113: 297-306.

Bellido F. and R. Hancock. 1994. Susceptibility and resistance of P.aeruginosa to antimicrobial agents .In: Campa M, Bendinelli M, Friedman H, eds. P.aeruginosa as an 
opportunistic pathogen. New York, Plenum Press. 32148.

Bilal N.E., M. Gedebou and S. Al-Ghamdi. 2002 .Endemic nosocomial infections and

misuse of antibiotics in a maternity hospital in Saudi Arabia . APMIS. 110 (2):140-7. Breen N.E., D.J. Durnam and S. K. Obendorf. 1984. "Residual Oily Soil Distribution on

Polyester/Cotton Fabric After, Laundering with Selected Detergents at Various Wash Temperatures" Tesr. Res. 1, 54: 198-204.

Boyce J.M., N.L. Havill, C. Kohan, D.G. Dumigan and C.E. Ligi. 2004. Do infection control measures work for methicillin-resistant Staphylococcus aureus? Infect Control Hosp. Epidemiol. 25: 395- 401.

Cardo D.M., P.S. Falk and C.G. Mayhall. 1993. Validation of surgical wound classification in the operating room .Infect Control Hosp. Epidemiol. 14:155.

Callaghan I.1998. "Bacterial contamination of nurses' uniforms: a study. Nurs Stand. 23 29; 13(1):37-42.

Emori G.T., D.H Culver., T.C Horen and et al. 1990. National nosocomial infections system (NNIS): description of surveillance methods .Am. J. Infect. Control. 19:19.

El Schahawi D. M., O. Assadian, A. Blackly, M. Stadler, E. Pernicka, J. Bergerand et al.2010. Evaluation of decontamination efficacy of new and reprocessed microfiber cleaning cloth compared with other commonly used cleaning cloths in the hospital. Am.J. Infect Control. 38: $289-92$

Ensayef S., S. Al-Shalchi and M. Sabbar. 2009. Microbial contamination in the operating theaters: a study in a hospital in Baghdad. Eastern Mediterranean Health Journal.15 (1): 219- 23.

Franklin R. Cockerill III, J. G. Hughes, E. A. Vetter, R. A. Mueller, A. L. Weaver, D. M. Ilstrup, J. E. Rosenblatt and W. R. Wilson .1997. Analysis of 281,791 consecutive blood cultures performed over an eight-year period: trends in microorganisms isolated and value of anaerobic culture of blood .Clin. Infect. Dis. 24(3):403-18.

Figan S., S. Koren, A. Cencic and S. Sostar-Turk. 2007. "Antimicrobial disinfection effect of a Laundering procedure for hospital textiles against various indicator bacteria and fungi using different substrates for stimulating human excrements". Diagnostic Microbiology and Infections disease. 57, 251- 257.

Ghada Abdel Fatah El Said. 2014."The Impact of some Different Fabric Construction of Cellulosic Blended Fabrics on the Resistance to some Fungi Types, Alex. J. Agric. Res. (59).2.

Ghosh S. 2000. "Medical Textiles "The Indian Textile Journal .March, Pp.10-14.

Hanan Lotfy Al Gamel. 1998. Methods of assessing care for clothes and upholstery in some hospitals and Hotels in Alexandria, Egypt. MS.Thesis, University of Alexandria,Egypt.

Heba Khamis Abdel Tawab Mabrouk. 2007. "Quality of design and produce standards of some Textile products used in surgical rooms". MS. Thesis. Helwan University, Egypt.
Herold B.C., L.C. Immergluck, M.C. Marnan and et al. 1998. Community acquired Methicillin resistant Staphylococcus aureus in children with no identified predisposing risk . JAMA. 279-593.

Hirai Y. 1991 .Survival of bacteria under dry conditions: from a viewpoint of nosocomial infection. J. Hosp. Infect. 19:191-200.

Hooker E.A., S. Allen, L. Gray and C. Kaufman. 2012. "A Randomized Trial to Evaluate a Launderable Bed Protection System for Hospital Beds," ARIC.J. 1-27.

Huda I. 2007. "Textiles and renewed high-microbial resistance: hard to install thermal Alhalimin". Newsletter textile industries support the spinning and textile industry fund, Egypt

Khadija Rosie k. G. 2005. "Materials and Clothing in Health and Disease". College of Education, Jeddah, Kingdom of Saudi Arabia.

Khadija Y.S. Alden Elaali. 2008. " Microbial contamination and methods of resistance from Al-Hada Armed Forces Hospital and King Faisal Hospital in Taif, Ph.D.Thesis King Saud University, Kingdom of Saudi Arabia.

Klevens R.M., M.A. Morrison, J. Nalde and et al. 2007. Invasive methicillin - resistant Staphylococcus aureus infections in the United States. JAMA. 298:1763.

Lidwell O.M.and E.J Low Bury. 1950. Survival of bacteria in dust: effect of atmospheric humidity on survival of bacteria in dust .J. Hyg. 48:21-7.

Loh W. ‘W. Ng and J. Hottan. 2000." Bacterial flora on the white coats of medical students". J . Hosp. Infect. 65:4568.

Moataz M. 2005. Surveillance of nosocomial infections at a Saudi Arabia military hospital for a one-year period .Ger Med Sci. 3: Doc 06.

Manal Al Bakery Ahmed. 2010."Clothing Men's Health in the 21 st century". Specific Educational journal May (17).

National Nosocomial Infections Surveillance System .Nation Nosocomial Infections Surveillance (NNIS) System Report, data summery from January 1992 to June 2002, issued August .2002. .Am J Infect Control. 30:458-75.

Neely An., V. Gallardo, E. Barth, R.A. Hauqland, G.D. Warden, and S.J. Vesper. 2004" Rapid monitoring by quantitative polymerase chain reaction for pathogenic Aspergillus during carpet removal from a hospital" Infect. Control Hosp. Epidemiol. 25 (4): 350- 2.

Neely AN. N. and M.P. Maley. 2000 "Survival of Enterococci and Staphylococci on Hospital Fabrics and Plastic ". J. Clin. Microbial. 38 (2):724- 726.

O'Connor H. 2000. Decontaminating beds and mattresses. Nurs Times, 96: 2- 5.

Parkash, D. Pardeshi and Sujata, G. Manjrekar. 2002. Medical Textile: New Avenue of textiles Applications"The Indian Textile Journal.13-22.

Pena C. et al. 2003. An outbreak of carbapenem resistant in a urology ward. Clinical microbiology and infection. 9:93843. 
Pinon A., J. Gachet, V. Alexandre., S. Decherf and M.Vialette. 2013. Microbiological contamination of bed linen and staff uniforms in a hospital. Advances in Microbiology. 3: 515-519.

Pittet D. and R.P. Wenzel. 1995. Nosocomial bloodstream infections. Secular trend in rates, mortality, and contribution to total hospital deaths. Arch Intern Med. 155 (11): $1177-84$.

Rao N., S. Jocobs, L. Joycc. 1988. Cost-effective eradication of an outbreak of methicillin resistant Staphylococcus aureus in a community teaching hospital. Infect Control Hosp Epidemiol. 9:255.
Rehab J. I. Abdel Hady. 2006."Effect of Wool and Blended Fabrics Finishing on Microorganisms Resistance to have the Functional performance properties of end use". M.S. Thesis, Tanta University. Egypt.

Sonia M. Shipoon. 2009. "Effect of upholstery weave construction of living room on the presence, growth and reproduction of fungi", Ph.D. Thesis Alexandria University; Egypt.

Teufel L., K.C. Schuster, P. Merschak, T. Bechtold and B. Redl. 2008. Development of a fast and reliable method for the assessment of microbial colonization and growth on Bacterial colonization of textiles. J. Mol. Microbiol. Biotechnol. 14, 193-200

\section{الملذص العري \\ التلوث الميكروي لبهن المنتجل النسيجية للعنلية الصحية في طستثفيلت محائلة الأهساء، المملكة العربية اللسونية \\ النعلم محمد للسيد البوزيد، نفين بهاء البن غافم المية}

الأسرة، و(ب\%\%)، (عץ\%) من التغيرات ف ي المحت -وى

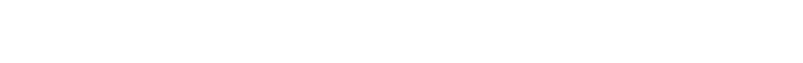

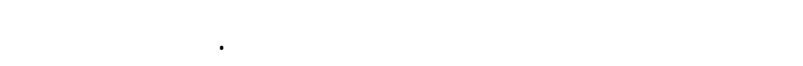

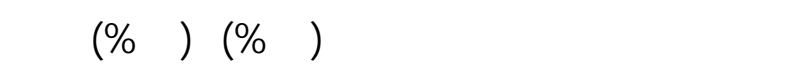

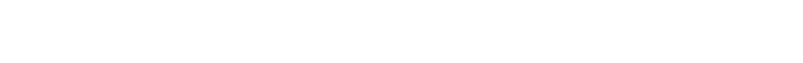

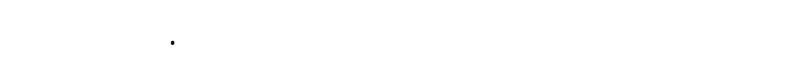

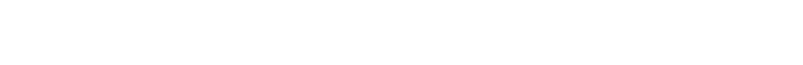

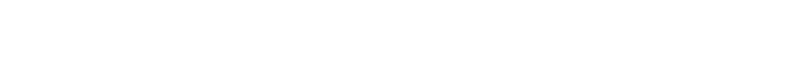

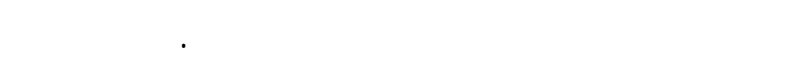

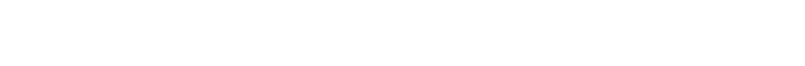

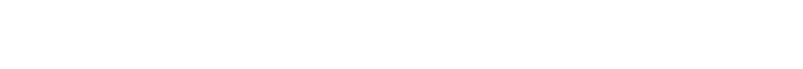
كان لها تأثيرا اليجابيا على عدد الخمائر.
لجريت هذه الدرلسة بهوف درلمة التا ـوث الميكروب ي

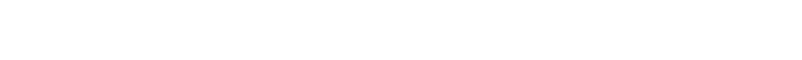

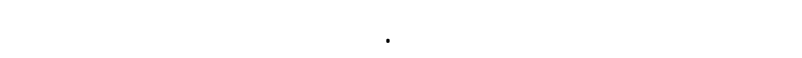
الميدلنية عن وجود دلالة إحصائية بين التلوث الميكروب عي المينية المينية

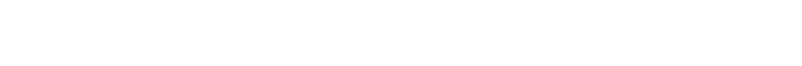

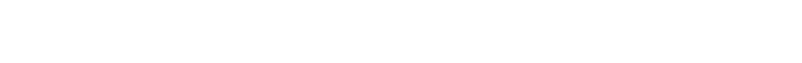

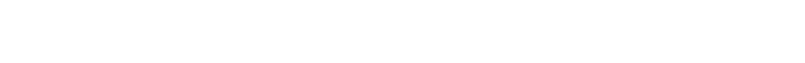

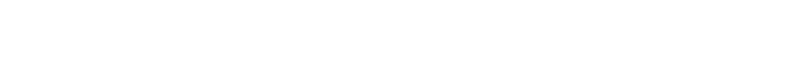

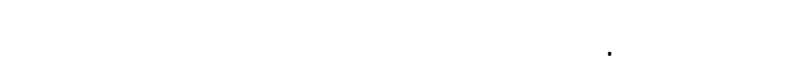

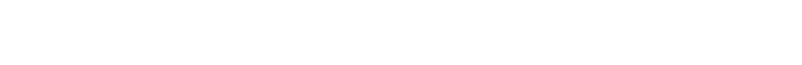

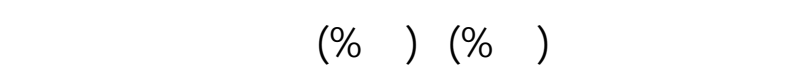

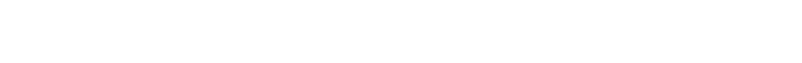

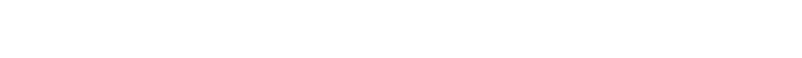

